\title{
ORGANIZED VIOLENCE AND THE FUTURE OF INTERNATIONAL LAW: A PRACTITIONER'S VIEW OF THE EMERGING ISSUES
}

\author{
by Charles J. Dunlap, Jr.
}

I would like to thank the American Society of International Law for allowing me this opportunity to discuss some emerging issues of international law as it relates to the organized violence we know as war. I should say that my assignment is greatly facilitated by a paper that the U.S. Army's Strategic Studies Institute very kindly published for me this past January. That essay, Technology and the Twenty-first Century Battlefield: Re-Complicating Moral Life for the Statesman and the Soldier, ${ }^{1}$ was written with the support of the Carnegie Council on Ethics and International Affairs, which is sponsoring a major project examining the legal and ethical issues of future war. I intend to draw heavily upon my essay for many of my remarks.

That said, I must make it clear that the views expressed are mine alone and do not necessarily reflect the official policy or position of the U.S. Air Force, the U.S. Department of Defense, or the U.S. Government. Likewise, the views expressed do not necessarily reflect the official policy or position of the Carnegie Council on Ethics and International Affairs.

More than anything else, the task of legal advisors to modern militaries has been complicated by the emergence of new technologies. Enormous changes brought about by the introduction of microchip-based systems have stimulated what has been called a "revolution in military affairs" (RMA). ${ }^{2}$

Advanced precision-guided munitions $(\mathrm{PGMs})^{3}$ are a good illustration of the militarization of the new technologies. PGMs have led many to assume that we are on the threshold of a more humane if not more law abiding era of warfare.

Such assessments, reinforced by oft-televised pictures of PGMs in operation, helped create new paradigms and expectations about the conduct of war. In his book, Beyond the Wild Blue: A History of the U.S. Air Force 1947-1997, William Boyne observed that today's military leaders must deal with two related aspects of post-Vietnam and post-Gulf War America. The first is the growing aversion in both the electorate and the uniformed ranks to incurring virtually any friendly casualties in military operations. ${ }^{4}$ The second, which Boyne points out "is unusual in history," requires wars to be won with "a minimum number of casualties inflicted on the enemy." Such expectations are much beyond the standards required by the international law of armed conflict (LOAC).

\footnotetext{
${ }^{1}$ Charles J. Dunlap, Jr., Technology and the Twenty-first Century Battlefield: Re-Complicating Moral Life for the Statesman and the Soldier, U.S. Army Strategic Studies Institute, Jan. 15, 1999.

${ }^{2}$ For a discussion of "the revolution in military affairs" in the information age see generally, Select Enemy. Delete., ThE ECONOMIST, March 8, 1997, at 21; Eliot A. Cohen, A Revolution in Warfare, FOREIGN AFFAIRS, Mar./Apr. 1996, at 37; Andrew F. Krepinevich, Cavalry to Computers: The Pattern of Military Revolutions, THE NATIONAL INTEREST, Fall 1994, at 30; and James R. Fitzsimonds and Jan M. Van Tol, Revolutions in Military Affairs, JOINT FORCE Q., Spring 1994, at 24.

${ }^{3}$ There are at least six categories of PGMs: (1) "man-in-the-loop" weapons such as laser-guided bombs which require an operator to "illuminate" the target or weapons that have on-board sensors which allow an operator to guide the weapon to the target; (2) autonomous weapons relying only on inertial navigation systems (INS) and autonomous weapons updated by Global Positioning Satellites (GPS) for guidance to the target; (3) autonomous weapons with terrain-aided INS/GPS systems; (4) autonomous weapons with INS/GPS systems and template matching algorithms for guidance; (5) anti-emitter PGMs that rely on onboard systems to home on emitting targets such as enemy radars; and (6) PGMs with "smart" submunitions that use various sensors to guide themselves to targets. See JOHN BIRKLER ET AL., A FRAMEWORK FOR PRECISION CONVENTIONAL STRIKE IN POST-COLD WAR MILITARY STRATEGY, at 6-11 (1996).

${ }^{4}$ Walter J. Boyne, Beyond the Wild Blue: A History OF THE AIR FORCE 1947-1997, at 7 (1997).

${ }^{5}$ Id.

${ }^{6}$ Id.
} 
We have already experienced the implications of this new paradigm. For example, the Gulf War air attack on Iraqi forces retreating down what is now popularly known as the "Highway of Death" fully complied, in my view, with the law of armed conflict. Nevertheless, uncertainties as to the impact on world opinion of the shocking televised images of the destruction contributed to the decision to end the ground war after only one hundred hours. This is, perhaps, a good example of why perceptions of the lawfulness of the conduct of military operations are so important. Professors W. Michael Reisman and Chris T. Antoniou explain:

In modern popular democracies, even a limited armed conflict requires a substantial base of public support. That support can erode or even reverse itself rapidly, no matter how worthy the political objective, if people believe that the war is being conducted in an unfair, inhumane, or iniquitous way. ${ }^{7}$

Of course, one hopes - and rightly expects - that American troops will fight in an ethical and lawful way simply because it is the right and moral thing to do. But as Reisman and Antoniou indicate, there are very practical and almost Machiavellian reasons for doing so these days. In order to succeed in modern conflicts, that is, to maintain the Clausewitzean notion of the "people's" support, it is necessary to act in compliance with international legal mores not only in fact, but also in perception.

This new paradigm - which is more a political requirement than a legal one-is generally understood by the current generation of military officers, at least in the United States. Most military personnel are, for example, well aware of the law of armed conflict and especially the importance of avoiding collateral damage and civilian casualties. My own experience during Operation Desert Fox in December 1998 convinces me that as a nation we have enjoyed considerable success at ensuring that our military personnel have received the necessary training. Rarely were there any instances in which serious LOAC issues, per se, were raised. If anything, there was a predisposition to take extraordinary steps beyond those required by international law.

Complicating military operations today is the new technological capability of the global news media to examine every detail of virtually any use of force. Thus, military operations are very rapidly subject to judgment in the court of world opinion. As a practical matter, this means that military leaders must not only act in a lawful fashion, they must be able to prove that they have done so. Consider the situation that arose in connection with the raid by U.S. forces on a pharmaceutical factory in the Sudan in August 1998.

This facility was believed by American intelligence to be, among other things, connected with a precursor compound, EMPTA, used in the manufacture of the nerve gas VX. Following the raid, however, the news media widely reported that the plant also manufactured medicines, thus raising questions about the propriety of the strike. Initially, U.S. authorities were reluctant to release any details of the information justifying the attack. However, pressure from the world community, including several allies, eventually resulted in a more specific accounting.

In the future military leaders contemplating an operation against an urbanized, dual-use target must accept that they may very likely be obliged if not by law, then by popular opinion, to disclose supporting evidence. Where the sources and methods of the intelligence systems that provide such data are too sensitive to allow such disclosure, consideration must to be given to identifying a different target or node, one evidenced by less sensitive sources. In other words, military leaders must be prepared to openly prove the legitimacy of the targeting

${ }^{7}$ W. Michael Reisman and Chris T. Antoniou, The Laws of War, at xxiv (1994). This trend has led Edward Luttwak to argue that an even greater investment in technology is required because modern democracies simply cannot tolerate casualties. See Edward Luttwak, Post-Heroic Armies, FOREIGN AFFAIRS, July/Aug. 1996, at 33 . 
decision or risk losing the critically important perception of legal and ethical correctness so important to the use of force by democracies.

Dual-use targets-targets having both civilian and military applications-will present increasingly difficult legal and ethical challenges. Attacks against infrastructure-including dual-use electrical grids and communications systems that support war-making capacity-have long been a staple of the American way of war. Using advanced PGMs, the U.S. military now has the capability to attack such targets with tremendous accuracy, often causing little, if any, apparent collateral damage.

It would be a mistake, however, to conclude that such precise attacks necessarily obviate legal and moral complications just because the immediate casualties (including noncombatant losses) may be few. ${ }^{8}$ Noncombatants in modern and modernizing societies are increasingly dependent upon such infrastructure for everything from powering water purification plants to managing essential food and health delivery systems to 911 calls.

Clearly, the secondary or "reverberating effects," that is, the effects beyond the relatively small immediate losses caused by the kinetic effects of a PGM, may be quite devastating to noncombatants in vulnerable, technology-dependent societies. ${ }^{9}$ In a penetrating article in the Fletcher Forum of World Affairs, Navy Commander James W. Crawford explains:

Precision technology limits the immediate and direct harmful effects of aerial bombardment. However, one must take issue with the assertion that the systematic destruction of the civil infrastructure through the use of precision weapons actually reduces the harmful effects of war. Ironically, the very capability of precision potentially augers greater collateral casualties, not less ... [PGMs are] clearly an efficient and effective application of force . . . Unfortunately, such a methodology not only impedes the enemy in some respects, but it also eliminates civilian life-support systems. ${ }^{10}$

This does not, of course, mean that such systems cannot be attacked. What it does mean is that military leaders and their legal advisors need better decision-support tools. They need the data to allow them to evaluate whether or not the military advantage likely to be achieved is outweighed by the adverse effects on noncombatants and their property; in other words, they need the information necessary to conduct the "proportionality" analysis required by international law and ethical warfare. ${ }^{11}$

One way of obtaining the necessary tools and data might be to employ the new modeling and simulation techniques now becoming available. For example, using data drawn from the Joint Resource Assessment Data Base, the U.S. Strategic Command's Strategic War Planning System can project the expected numbers of killed and injured when a given nuclear weapon is delivered by a designated platform in a certain fashion on the selected target. ${ }^{12}$ Similar

\footnotetext{
${ }^{8}$ See Winn Schwartau, The Ethics of Civil Defense and Information Warfare, J. NAT'L COMPUTER SECURITY ASS'N (NCSA NEWS), June 1997, at 15, 16-17.

${ }^{9}$ See Commander James W. Crawford, The Law of Noncombatant Immunity and the Targeting of National Electrical Power Systems, 21 FLETCHER F. WORLD AFF. 101 (Summer/Fall 1997).

${ }^{10}$ Crawford, supra note 9, at 54.

"Essentially, the concept of proportionality requires commanders to refrain from attacks when it "may be expected to cause incidental loss of civilian life, injury to civilians, damage to civilian objects or combination thereof, which would be excessive in relation to the direct and concrete military advantage anticipated." See DEPARTMENT OF THE AIR FORCE PAMPHLET(AFP) 110-31, International Law-The Conduct of Air Operations, Nov. 19, 1976, para. 5-3c(1)(b)(I)(c).

${ }^{12}$ The system uses terms that have specific definitions and this affects the evaluation. For example, "casualties" are defined as the "estimated number of people who die or receive injuries that require medical treatment due to short term effects (6 months) of nuclear detonations." "Population at Risk" is defined as the "total civilian population in danger of dying, independent of shelter, from short term (6 months) effects of nuclear detonations." See MEMORANDUM, Acronyms/Definitions Used in SIOP Analysis (U), USSTRATCOM PLANS AND POLICY DIRECTORATE, FORCE ASSESSMENT BRANCH (Apr. 1997) (on file with author).
} 
systems might be developed to analyze the effects of conventional attacks on high-technology networks.

However, modeling and simulation themselves present significant re-complications for military leaders. Specifically, are these leaders legally or morally obliged to follow the model? Suppose, for example, that a decision maker chooses a course of action that the model shows will result in greater noncombatant casualties than another available option. Since the legal duty is to "take all feasible precautions" to avoid noncombatant casualties, ${ }^{13}$ if a computer calculates that a certain method of attack among several options most minimizes noncombatant losses, does that automatically preclude consideration of the other options? If a commander selects another option, has he or she failed to do everything "feasible" to avoid noncombatant losses? How will a commander justify a decision that seems to fly in the face of dispassionate computer logic?

As technology progresses one might fairly expect the fidelity of the models to improve, ${ }^{14}$ but it is not yet clear that they can ever substitute for the judgment of the commander in the performance of the war-fighting art. The linear, mathematical nature of computer processes may never be able to replicate the nonlinear and often unquantifiable logic of war. ${ }^{15}$ The history of human conflict is littered with examples of how military forces achieved results that no algorithm would have predicted. ${ }^{16}$ Still, the world increasingly considers reports provided by an electronic brain innately more authoritative than human-derived analyses. Thus, it may well behoove legal advisors to military leaders in future conflicts to somehow capture their rationale when selecting a computer-produced option that appears to be more casualtyintensive than another course of action assessed by the same source.

There is a flip side to the issue of dual-use facilities, and that is the increasing reliance of the United States' own forces upon them. International law admonishes belligerents to separate military and civilian facilities. During the Gulf War, for example, Iraq was excoriated in much-reported incidents in which combat aircraft and other military equipment were deliberately placed in proximity to noncombatant cultural and religious facilities. Nevertheless, we are seeing troubling trends in our own country. Because of budgetary pressures, as well as the nature of technology, the United States can no longer afford to maintain many hightechnology capabilities separate from those found in the civilian sector. Nowhere is this use more extensive than in the communications arena. The U.S. armed forces-like other modern militaries-relies heavily upon the civilian communications infrastructure; more than ninety percent of its messages flow through commercial channels. This has caused concern to Professor Dan Kuehl of the National Defense University's School of Information Warfare. He says that this "growing intermingling in the integrated information society of systems used and needed by both the military and civil sides of society . . . is making our national information

${ }^{13}$ See AFP 110-31, supra note 11, para. 5-3c(1)(b)(I)(c).

${ }^{14}$ See generally Paul R. Camacho, Further Development in the Construction of Political Action Expert Systems Software: Fuzzy Logic Techniques on Social Science Variables, a presentation for the Biennial International Conference of the Inter-University Seminar on Armed Forces and Society, Baltimore, Md., Oct. 24-26, 1997 (unpublished paper on file with author).

15 "War is typically nonlinear, meaning the smallest effects can have unpredicted, disproportionate consequences." See Jeffrey McKitrick, et. al, Revolution in Military Affairs, in BATTLEFIELD OF THE FUTURE (Air Univ., 1995). See also Glenn E. James, CHAOS THEORY: THE ESSENTIALS FOR MILITARY APPLICATIONS 57-95 (Newport Paper No. 10, Naval War College, 1996) (discussing the limitations of computer modeling).

${ }^{16}$ Robert N. Ellithorpe, Warfare in Transition? American Military Culture Prepares for the Information Age, at 4, a presentation for the Biennial International Conference of the Inter-University Seminar on Armed Forces and Society, Baltimore, Md., Oct. 24-26, 1997 (unpublished paper on file with author) ("History has demonstrated the fatal error of military decisions based on the use of scientific and technical analysis at the expense of understanding the warfighting art."). 
infrastructure a viable, legal and ethical target in the case of conflict." 17 Military leaders thus have a moral and legal responsibility to carefully consider the implications of creating bona fide targets out of systems on which noncombatants are increasingly dependent.

Of particular concern in this regard is the role of space in future conflicts. Many space systems have dual uses. Satellites provide critical surveillance and communication support for both civilian enterprises and U.S. forces. The same is true with respect to potential adversaries. According to General Charles A. Horner, the Gulf War hero and former commander of the U.S. Space Command, space systems are "fundamental to modern warfare." 18 While there are some purely military space systems today, the U.S. military itself relies heavily on civilian satellites, many of which are owned by international consortiums. These same systems are vital to the health of purely civilian activities in many nations.

Because of the importance of space to military operations, the former commander in chief of the U.S. Space Command, General Howell Estes, has argued that war in space is inevitable. ${ }^{19}$ Unsurprisingly, therefore the U.S. Space Command has established a Space Warfare Center and has aggressively advocated having "space" declared its area of operations so as to facilitate planning for conflict there. ${ }^{20}$ Similarly, the former Air Force Chief of Staff, General Ronald Fogelman predicted that space would someday become the service's principal focus, the service evolving from an air and space force to a space and air force. ${ }^{21}$

However, there is little international appetite for the notion of conflict in space. Virtually every treaty related to space asserts that it is to be used only for "peaceful purposes." 22 Is this because the community of nations has suddenly become pacifist? Not likely. The real reason is self-interest: Most nations have increasing dependence upon space systems yet few have any capability to conduct operations there. The United States, as the leading spacefaring nation, may not be as vulnerable to the technical challenges that deter others from space operations. However, it may well find itself restrained from space warfare by ethical and political considerations. Space systems present the classic legal and moral conundrum posed by multiuser items: How do you attack them without causing disproportionate injury to noncombatants and their property, especially when the same system is used by nations not involved in the conflict?

As a practical matter, it is difficult to foresee many scenarios in which a proportionality analysis would justify attacks on multi-user systems. This is especially true as noncombatants in a growing number of countries become ever more reliant on space-based technologies for a whole range of essential communications and other services. In a fascinating article in the autumn 1998 issue of Parameters, Frederick Kagan points out that just such considerations are likely to make it politically infeasible for the United States to ever wage space warfare. ${ }^{23}$

This may, however, provide an opportunity for legal considerations to dovetail with practical military and political realities. In other words, it may be shrewder to now pursue a legal regime that declares space a "sanctuary" similar to that afforded communications

${ }^{17}$ Daniel Kuehl, The Ethics of Information Warfare and Statecraft, paper presented at InfoWARcon '96, Washington, D.C., (Sept. 10, 1996) (copy on file with the author).

${ }^{18}$ As quoted by George Wilson. See George C. Wilson, Like It or Not, Space Warfare is Way of Future-and Past, AIR FORCE TIMES, June 28, 1994, at 70.

${ }^{19}$ See Jennifer Heroema, A.F. Space Chief Calls War in Space Inevitable, SPACE NEWS, Aug. 1-18, 1996 , at 4.

${ }^{20}$ See U.S. SPACE COMMAND, U.S. SPACE COMMAND VISION FOR 2020 (1997), at 6.

${ }^{21}$ As quoted in U.S. AIR FORCE, GLOBAL ENGAGEMENT: A VISION FOR THE $21^{\text {st }}$ CENTURY AIR FORCE (1997), at 7.

${ }^{22}$ See, e.g., Article I, Treaty on Principles Governing the Activities of States in the Explorations and Use of Outer Space, Including the Moon and Other Celestial Bodies, Jan. 27, 1967, 18 U.S.T. 2411, I.I.A.S. No. $6347 ; 610$ U.N.T.S. 205 (the "Outer Space Treaty"). See generally, Richard A. Morgan, Military Uses of Commercial Communications Satellites: A New Look at the Outer Space Treaty and "Peaceful Purposes", 60 J. AIR L. \& COM. 237 (Fall 1994).

${ }^{23}$ Frederick W. Kagan, Star Wars in Real Life: Political Limitations on Space Warfare, PARAMETERS Autumn 1998 , at 112 . 
facilities located in neutral territory. This would permit any nation to use space for communications, surveillance and comparable activities-even during armed conflicts-with the systems not being subject to attack.

Arguably, a sanctuary strategy would renew the United States' original policy toward space. President Eisenhower established a "self-imposed space sanctuary policy ... [in order to] establish the principle of freedom of space, to protect U.S. satellites from interference, and to avoid an arms race in space." "Neutralizing" space would not appear to degrade America's war-fighting capability, provided U.S. space systems were therefore protected. In any event, existing legal and policy norms already limit or preclude attack on the multiuser international systems that adversaries will rely upon during war.

This space neutralization proposal would not preclude subspace means that selectively deny adversaries' military forces the use of signals from space platforms. However, the development of lasers and other space weapons would be prohibited, although passive defensive measures (hardening, stealth, etc.) would be allowed. Accordingly, the proposal would not be inconsistent with current U.S. space policy, which advocates diplomatic and legal "measures to preclude an adversary's hostile use of space systems and services." ${ }^{25}$ Some may - and, in fact, already do-argue that the movement of weaponry into space is inevitable and cannot be effectively banned. ${ }^{26}$ But the remarkable history of nuclear arms control (during which many of the same arguments were made) leaves room for optimism-especially if action is taken soon.

Paralleling the problematic commingling of military and civilian high-technology facilities is the tremendous infusion of civilians into formerly military jobs that has occurred of late. In the past few years, there has been a determined effort to convert as many military billets as possible to less expensive civilian positions. ${ }^{27}$ These initiatives have resulted in thousands of civilians filling what were once military assignments at stateside bases and, increasingly, on overseas deployments. ${ }^{28}$

The trend toward civilianization exacerbates the long-held fear that new technology requiring ever-greater civilian involvement will cloud a principle vital to the law of armed conflict: ${ }^{29}$ the requirement to distinguish between combatants who could be legitimately attacked, and noncombatants who could not. As with civilian objects, current international law requires belligerents to exercise "care to separate individual civilians and the civilian population as such from the vicinity of military objectives." 30

International law does, of course, recognize that civilian technicians and contractors are necessary for modern militaries. It holds that they are subject to attack only when actually performing tasks in support of the armed forces. Unlike uniformed personnel, they are not ordinarily targeted when away from their jobs. If captured, they are entitled to treatment as prisoners of war. ${ }^{31}$ Nonetheless, the law has always held that noncombatants' "immunity from

${ }^{24}$ See Michael R. MANTZ, The New Sword: A Theory of Space Combat Power (Air University Press, May 1995), at 12 (emphasis added).

${ }^{25}$ National Science and Technology Council, National SPACE POLICY (White House Press Release, Sept. 19, 1996), at 6.

${ }^{26}$ See e.g., Ben Bova, Laser foes forget crossbow's history, USA TODAY, January 7, 1998, at 15.

${ }^{27}$ The GAO found that $45 \%$ of military personnel performed support functions that could be done by civilians for an average of $\$ 15,000$ less. See Tom Bowman, Shift Military Support Jobs to Civilians, Close Inefficient Facilities, GAO Urges, BALTIMORE SUN, April 5, 1997, at 4.

${ }^{28}$ Katherine M. Peters, Civilians at War, GovernMENT EXECUTIVE, July 1996, at 23.

${ }^{29}$ AFP 110-31, supra note 11, para. 3-5.

${ }^{30}$ W. Hays Parks, Air War and the Law of War, 32 A.F. L. REV. 1,168 (1990).

${ }^{31}$ AFP 110-31, supra note 11, para. 3-3. 
damage and harm was predicated upon their obligation to abstain from hostile acts. If they took action against a party's armed forces, they automatically lost immunity." 32

Unfortunately, reduced civilian immunity appears to be exactly the direction warfare is heading. Defense News characterized the large numbers of civilian technicians required for the U.S. Army's digitized battlefield as "surrogate warriors." 33 Indeed, the operation of hightechnology systems is moving civilian technicians and contractors from traditional support functions to what are arguably "hostile" activities. For example, a civilian technician who helps execute a computerized offensive information attack against an enemy system may well have gone beyond mere 'support.' For its part, the U.S. Air Force has openly announced its intention to deploy civilians operationally. In Global Engagement: A Vision for the $21^{\text {st }}$ Century Air Force the service states that "combat operations in the $21{ }^{\text {st }}$ Century" will broaden "the definition of the future operator." 34 It goes on to state that: "in the future, any military or civilian member who is experienced in the employment and doctrine of air and space power will be considered an operator." 35

Once civilian technicians or contractors become involved as "operators" in "combat operations", they risk being characterized as "unlawful combatants" under international law. ${ }^{36}$ This has a number of consequences, including the possibility that, if captured these civilians can be tried and punished for their hostile acts, to include the same things for which a uniformed combatant would have immunity. ${ }^{37}$ It is very doubtful that many of these "surrogate warriors" are cognizant of their new status or comprehend the ramifications of it.

Another difficult challenge for legal advisors is that posed when military force is used in an effort to communicate "messages" to opponents. Although using force merely to terrorize noncombatant civilians is contrary to international law, affecting the mental state of an adversary, degrading morale, and eroding the will to continue the conflict can all constitute legitimate military objectives. ${ }^{38}$ The difficulty, as Geoffrey Best notes, lies in reliably quantifying such amorphous and often quite culturally specific psychological concepts to the point where one could reasonably conclude before the attack that a "definite military advantage" would be achieved. ${ }^{39}$

${ }^{32}$ Paul Kennedy and George J. Andreopoulos, The Laws of War: Some Concluding Reflections, in THE LAWS OF WAR: CONSTRAINTS ON WARFARE IN THE WESTERN WORLD 215 (Michael Howard, George J. Andreopoulos, and Mark L. Shulman, eds., 1994).

${ }^{33}$ See Bryan Bender, Defense Contractors Quickly Becoming Surrogate Warriors, DEFENSE DAILY, March 28, 1997 , at 490 .

${ }^{34}$ U.S. Air Force, Global Engagement: A Vision for the $21^{\text {st }}$ CENTURy Air ForCe (1997), at 7.

${ }^{35} \mathrm{Id}$., at 19.

${ }^{36}$ AFP 110-31, supra note 11, para. 3-3 provides:

An unlawful combatant is an individual who is not authorized to take a direct part in hostilities but does. The term is frequently used also to refer to otherwise privileged combatants who do not comply with requirements of mode of dress, or noncombatants in the armed forces who improperly use their protected status as a shield to engage in hostilities . . . Unlawful combatants are a proper object of attack while engaging as combatants ... If captured, they may be tried and punished.

See also Lt Colonel Robert W. Gehring, Loss of Civilian Protections Under the Fourth Geneva Convention and Protocol I, 90 MIL. L. REV. 49 (1980).

37 "Unlawful combatants" are not ordinarily considered "war criminals." Rather, they would be subject to prosecution under the domestic law of the belligerent who captures them, much as out-of-uniform saboteurs would be. During World War II, for example, the United States captured eight German saboteurs and executed six. See AMERICAN HERITAGE NEW HISTORY OF WORLD WAR II 276 (Rev. and updated by Stephen E. Ambrose based on the original text by C. L. Sulzberger, 1997).

${ }^{38}$ See U.S. Navy, Annotated Supplement to the Commander's Handbook of the Law of Naval Operations, Naval Warfare Publication (NWP) 9 (Rev.A) (1989) para. 8.5.1.2 (discussing the prohibition on the bombardment for the sole purpose of terrorizing civilians) and Parks, supra note 27, at 142 (discussing the general proposition of psychological purposes as military objectives).

${ }^{39}$ See GEOFFrey BEST, LAW AND WAR SINCE 1945 274-275 (1994). 
Targeting for psychological purposes can be a particular problem for U.S. legal advisors as Americans in general are not always very good at understanding other cultures. Edward L. Rowney, a retired general officer and former U.S. arms control negotiator, has commented:

Our biggest mistakes stem from the assumption that others are like us, when in fact, they are more unlike than like us. We insist on ascribing to others our cultural traits, not recognizing that we have different objectives due to our unique historic backgrounds and sets of values. ${ }^{40}$

H.R. McMaster observes in his book Dereliction of Duty, for example, that the graduated application of airpower during the Vietnam War-intended to signal U.S. resolve to support South Vietnam yet do so in a way that the United States believed demonstrated restraint-wholly misperceived North Vietnamese thought processes.

Graduated pressure was fundamentally flawed ... the strategy ignored the uncertainty of what was the unpredictable psychology of an activity that involves killing, death, and destruction. To the North Vietnamese, military action, involving as it did attacks on their forces and bombing their territory, was not simply a means of communication. Human sacrifice in war evokes strong emotions creating a dynamic that defies systems analysis quantification. $^{41}$

Beyond the difficulties that cultural differences may produce in terms of conducting a proper proportionality analysis, they also may be the source of tomorrow's wars, if Harvard University political scientist Samuel P. Huntington is correct. He contends that future conflicts will likely be clashes between civilizations with fundamentally different psychological orientations and value sets than those of the West. ${ }^{42}$

Within some of these civilizations, I submit, there is another disturbing phenomenon brewing, one with grave implications for those concerned with compliance with international law in bellum. It is described in a brilliant piece by Ralph Peters, then a U.S. Army major, that appeared in the summer 1994 issue of Parameters. In it, Peters delineated what he calls "the New Warrior Class," a multitude which he contends "already numbers in the millions." Peters says that in the future,

[America] will face [warriors] who have acquired a taste for killing, who do not behave rationally according to our definition of rationality, who are capable of atrocities that challenge the descriptive powers of language, and who will sacrifice their own kind in order to survive.

Along similar lines, military historian John Keegan observes that the post-Cold War world is experiencing the reemergence of "warrior" societies in Chechnya, the Balkans, Afghanistan, Somalia, central Asia and elsewhere. These are peoples, he says, who are psychologically distinct from those of the West, and whose children are "brought up to fight, think fighting honorable and think killing in warfare glorious." A warrior in such societies, Keegan wrote in 1995, "prefers death to dishonor and kills without pity when he gets the chance."

I believe that we will see-and, indeed, have already seen - these adversaries wage what I call neo-absolutist war. It is war without rules, one that uses atrocity as a deliberate strategy. While this has occurred not infrequently in history, such warfare earns its neo- prefix by leveraging new technologies-along with the global media-in a variety of ways. Such opponents will attempt to turn our moral, ethical and legal values against us. Why? Because it seems to provide a way to offset the technological and military strengths of U.S. forces without actually defeating those forces on the field of battle.

\footnotetext{
${ }^{40}$ Edward L. Rowney, Tough Times, Tougher Talk, AMERICAN Legion Magazine, May 1997, at 24, 25-26.

${ }^{41}$ H.R. MCMASTER, DERELICTION OF DUTY (1997), at 327 (emphasis added).

${ }^{42}$ Samuel P. Huntington, The Clash of Civilizations AND the REMAKing OF World ORder (1996).
} 
The deaths of eighteen U.S. Army Rangers during a mission in Somalia in October 1993 were enough to derail U.S. policy there, even though from a purely military standpoint the raid achieved its objectives and the U.S. losses were miniscule compared with those of the enemy. What proved to be particularly effective, however, was the barbaric treatment of the body of a U.S. soldier. The widely televised images of the body being dragged through the streets of Mogadishu helped destroy the public support that the U.S. military needed to succeed in Somalia. Consistent with a neo-absolutist approach, the Somalis made no attempt to hide the savagery of their act.

Americans should also expect enemies to exploit the casualty aversion phenomenon discussed earlier in this paper-even at the expense of their own people. Such tactics may have been unintentionally inspired by the aftermath of the bombing of Baghdad's Al Firdos bunker during the Gulf War. Unbeknownst to coalition target selectors, that underground commandand-control facility was also being used to shelter the families of high Iraqi officials. After the devastating attack that destroyed the bunker, pictures of scores of bodies of women and children being pulled from the wreckage were broadcast worldwide. This caused U.S. leaders-concerned about adverse public reaction to the noncombatant deaths-to virtually end further raids on the Iraqi capital.

Though the decision to forego further operations against Baghdad had little effect on the outcome of the war, the precedent is important. The United States' response to the unexpected results of the Al Firdos bombing obviously suggests to some foes a cheap and reliable method of defending against U.S. strikes: cover the target with noncombatants. It seems that this tactic has been embraced by a number of opponents. Human shield tactics enabled the Serbs to discourage strikes by U.S. and other North Atlantic Treaty Organization planes by the simple expedient of chaining captured UN troops to potential targets. Libya has likewise threatened to surround the reported site of an underground chemical plant with "millions of Muslims" in order to ward off attacks. ${ }^{43}$

To reiterate, despite U.S. technological prowess that seems to herald an era of surgical attacks that limit noncombatant losses, I predict that adversaries will seek to offset U.S. military capabilities by turning American values and adherence to international law against the United States. The result may be organized violence even more savage than in the past. While there are some military strategies that can be employed to confront this new form of war, an important role is to be played by such efforts as the International Court of Justice now in place in The Hague. I think that there is real value to clearly demonstrating to the perpetrators of war crimes that they will be called to account for their actions. Indeed, I favor the use of military force to apprehend those suspected of committing atrocities.

That said, I must tell you that I do not support the new International Criminal Court in its present form. My opposition is on somewhat different grounds than what you may have heard from other speakers. I believe it is wrong-and unwise-to subject American soldiers to prosecution by a court that does not meet the minimum standards of the U.S. Constitution. In an era in which the United States must rely upon a professional, volunteer force, good civilmilitary relations mandates that the members of such a force be treated as far as possible like every other citizen. To do otherwise risks the alienation and isolation of the armed forces from society, a development much discussed lately in sociological circles and, in any event, one not in the interests of any democracy. What is more, the United States has repeatedly demonstrated that it will bring to justice within its own military system those persons accused of the commission of war crimes and other criminal acts.

Before closing, I wish to add a few more observations. I hope that my comments thus far indicate how necessary it is these days for legal advisers to have a thorough comprehension

${ }^{43}$ Libyans to form shield at suspected arms plant, BALTIMORE SUN, May 17, 1996, at 14. 
of not only of the applicable law but of the technical aspects of modern war. For example, in assessing what constitutes a hostile act or an expression of hostile intent justifying the use of force, one needs a sophisticated understanding of weapons, platforms and sensors. Legal advisers must also understand military strategy. In short, in order to be effective, the legal adviser must be as much of a student of military affairs as anyone in uniform.

It is my hope that one result of this ninety-third Annual Meeting will be improved communications between those scholars who think and write about the international law of armed conflict, and the military and civilian legal advisers engaged in the practice of it. Much of literature produced by even the most respected journals suffers from lack of appreciation of the new technologies of war and the technical aspects of their use. It appears that, all too frequently, writings are aimed at other like-minded academics. Not enough of the literature seems to be directed at the kind of practical, real-world issues that confront practitioners today.

Those wishing to actually have an effect on the practice of the international law of war may wish to consider writing focused articles in journals and magazines readily accessible to the military lawyer in both form and content. For example, Reisman and Antoniou's Law of $W r^{44}$ contains an excellent summary of a wide variety of international agreements, along with some exceptionally insightful commentary. There is an additional, very practical reason that I always take it with me when I am deployed for an operation: the publication conveniently fits into the pocket of my battle dress uniform.

Furthermore, I believe that a greater effort should be made to write LOAC-related books and articles that are aimed at educating the general public. An excellent example of a publication in which an in-depth examination of important LOAC issues is found in an entertaining and readable format is the recent book by Gary Solis entitled Son Thang: An American War Crime. ${ }^{45}$

In any event, I have only scratched the surface of the many issues in the area of war and international law that are emerging today. Finally, I wish to reemphasize that the comments and opinions I have presented are simply my personal views and do not represent those of the U.S. Government or any of its components.

\footnotetext{
44 Supra note 7.

${ }^{45}$ Gary D. Solis, Son Thang: AN American War Crime (1998).
} 